\title{
Horizontal housing property market
}

\author{
Nisa Zainudeen, Sepani Senaratna, \\ Suranga Jayasena, Raufdeen Rameezdeen
}

\begin{abstract}
Demand for housing in urban centres is a common issue. Colombo, the commercial capital of Sri Lanka, has been witnessing a surge of condominiums and housing estates in its core and peripheral locations in the past two decades due to economic liberalization coupled with policy directives aimed at an increased participation of the private sector. This paper presents a research study on factors affecting customer attraction and saleability of Housing Estates in Sri Lanka and the levels of customer satisfaction in these housing estates. The study is interesting because, satisfied customers are the backbone of the housing estate industry. Both structured and unstructured surveys were used for data collection; and the samples comprised property developers, customers and tenants. The study identifies six factors that affect significantly on demand for housing estates. It further analyse the factors that customers consider in opting for a house in a housing estate as opposed to other dwelling options. Then the study extends to model the customer satisfaction in the housing estates. The model is based on the definition of customer satisfaction: the extent to which a product perceived performance matches a buyer's expectations.
\end{abstract}

\section{Introduction}

Shelter is a primary need of the mankind. In the modern day's context, housing development is seen as a key issue to be addressed in the socio-economic and political agenda across the world, particularly in the developing countries where urban housing poses a challenge in the process of development. The post independent era in Sri Lanka characterizes a continual growth in the housing sector development irrespective of sluggish performance of other construction in its early years. Successive governments have given emphasis on housing development in their political agenda, thus leading to significant policy changes in housing over the six decades of its post independent history. However, private sector development in this sector has been insignificant during the earlier decades as the government played the major role in housing development. Over the last two decades, an increasing participation of the private sector has been witnessed as a result of policy changes and directives geared to promote private sector participation in line with the decrease of public sector investment in housing (Marga, 1986; Kawshala, 2002; Dasanayake, 2004; Nandagopan, 2005).

Colombo, the commercial capital of Sri Lanka, has undergone a sharp and steady growth in vertical and horizontal housing development over the last two decades as a result of policy changes coupled with population increase mainly due to in-migration. The rapid rise of condominiums have proven to be a very attractive business in terms of profitability, pay back and finance, as most of these are self financed due to pre-selling. The market potential for condominiums is apparent due to the obvious demand and the increasing supply of condominium property. Similarly, the horizontal housing development is rapidly expanding in the outskirts of Colombo city and shows potential to be financially a very attractive business for property developers.

Previous studies demonstrate the market potential for horizontal housing development (Dasanayake, 2004; Nandagopan, 2005). This paper offers an in-depth investigation into a selected sample of horizontal housing development in Colombo and suburbs in terms of customer satisfaction. This explains how the characteristics of a housing development would affect its saleability.

\section{Housing Estates}

According to Chandler et al (2005), people have made their homes in groups since the earliest times for protection from hostile outsiders, for economic reasons (markets and the exchange of services), and for social reasons (conversation at the communal well or local pub). The concept of housing scheme came into existence primarily owing to these reasons. A housing estate can be defined as a medium-to-low density residential area, usually part of a suburb of a town or city in contrast to high density housing, such as tower blocks, town housing or the older-style rows of terraced houses. Many housing schemes built during the twentieth century (and still being built) was intended for a relatively homogeneous population, for example, these populations would be either the elderly or families or people of a certain income level. 
In the previous stage, most of the homebuilders provided individual houses to customers, as per their wishes. But later it changed from individual housing to luxurious apartments and to the housing estates. In this context, competition between each home building company is increased, because each company targets the same group of customers. In such a scenario the best company will win long-term success and become the market leader of the housing industry.

Recently many companies have entered into the business of housing estate development in Sri Lanka. Due to high competition, they are concerned about their performances. To compete successfully in the long run, they assess their performance in the market place. Providing superior quality product and maintaining customers' satisfaction are becoming the ways the companies differentiate themselves from the competitors.

\section{Research methodology}

The aim of this study is to identify the characteristics of a housing development that affect its attractiveness and saleability, and to investigate the current status of customer satisfaction levels in housing estates in Sri Lanka.

First, a literature survey was carried out to find the demand and supply for housing estates in Sri Lanka. This was mainly obtained from newspapers, journals, articles, periodicals and websites. The field study comprised of both structured and unstructured survey techniques. Semi-structured questionnaire survey was carried out to a selected sample of property developers, customers and residents in housing estates to find the likely variables affecting the demand and supply of the housing estates and their perspectives on housing estates. The study was confined to Colombo and suburbs as majority of the hosing estates are coming up in these locations.

A structured questionnaire survey among the residents of five selected housing estates was carried out to ascertain the customer satisfaction. Ten residents from each estate totalling 50, were selected for the survey. The survey explored their personal housing history and their attitudes to the dwelling, the estate and house design and management structures, the image of the estate, security, issues regarding the services provided and ultimately the satisfaction with the present home. The data collected from residents enabled to suggest factors that are most significant in influencing people's decisions to live and buy properties in new housing estate developments.

\section{Factors affecting customer attraction and saleability of housing estates}

Customer attraction and saleability are often synonymous in housing market. Attractive schemes naturally enjoy high saleability. Among the factors identified through the survey focused on leading housing estate property developers in Sri Lanka, six factors were identified as most significant. They are location; attractiveness in design; attractiveness in prices and flexible payment schemes; reputation and experience of the developer; quality of the product; and, services offered.

Location is a key factor of attraction. Customers look for peaceful locations and with good access to work places and other facilities such as hospitals, shopping malls, schools for their children and banks. Therefore, if a housing estate is constructed in a central location close to above facilities, the saleability of such houses is higher.

In terms of design, developer should consider providing housing estates set in a pleasing residential neighbourhood designed to match modern day living. Designs of houses should be able to give the customer, a choice that is not just accommodative of his requirements in terms of living, but budget as well. Most of the developers offer various types of designs which can be altered according to the customer's wishes without changing the external appearance of the house. The saleability of a particular housing estate increases, if it is able to provide the concept of living in a greener, healthier environment, to one that has all amenities, utilities and comforts of city living.

Price is another significant factor that affects the saleability. Nowadays people have to fulfil their complex requirements with limited resources. In such a scenario, a customer is very much concerned about affordable house prices. Therefore, developers should provide attractive prices for the satisfaction of the customer. To improve the attractiveness and saleability of housing estates, developers tend to offer several house types for various price ranges in one estate for different customers. If the project is approved by the Board of Investment (BOI), the customers may have the advantage of duty free prices and of concessionary land values. Furthermore, it is important to offer many flexible payment schemes to suit the client's budget and income level. Understanding this concept, developers now present the payment schemes which can be tailor made for the buyer so that it will not be an additional burden to him. 
Reputation and experience of the developer is another significant factor that affects the saleability of housing estates. When a customer wants to purchase a house, he will look for the goodwill of the developer. If a developer has a good name in the industry for reliability, quality of the work, timely delivery and good relationship with the buyers, customer prefers to buy a house from him as customers do not have time to supervise construction activities. Therefore, they want to purchase a house from a developer who can be trusted in every aspect. The effort taken by the developer to maintain the name within the industry may result in attracting more customers for his schemes.

When the customer is satisfied with the quality of the product, the demand will be higher. Rising customer expectation and competition are setting new benchmarks for quality in housing development. Unlike in the past, clients are more concerned about whether they get what they should get. Therefore, maintaining the consistent quality in design, materials and construction is essential for the developer to become more efficient, flexible and competitive in today's changing industry environment.

Services provided by the developer in terms of other facilities and infrastructure directly affect the saleability of a house. Today people like to fulfil their requirements under one roof. Understanding this concept, many of these development schemes offer facilities such as shopping malls, swimming pools, playgrounds, tennis courts, basketball, day-care centres and gymnasium. Usage of these facilities is usually exclusive to residents and their guests. If such facilities are provided within the housing state, higher customer attraction would be expected. On the other hand a housing estate should be able to give the customer infrastructure such as better road networks, street lighting, water, electricity, telephone, drainage and waste treatment facilities, to increase the saleability.

\section{Customer's perspective on housing estates}

The saleability of a housing estate is largely dependant on the customers' perception. The customer survey focused on the facts that customers consider in opting for a house in a housing estate as opposed to other options such as a housing unit in a condominium or an owner-built house. Several factors were identified through this survey such as less time and knowledge needed for construction supervision, total living concept, neighbourhood and prestige, location and access, and security.

First, majority of the people who work, do not have free time to engage in supervision of construction work. Most of them cannot afford to have a supervisor to monitor the construction work. So what they are looking for is a "ready-made house" of superior quality. On the other hand, less knowledge in construction makes them reluctant to initiate their own construction project. Thus, buying a house from a housing estate is the ideal solution for them as the risk is minimal with a reputed and experienced developer.

Second, the "total living concept' emerged in USA and now practiced all around world is another reason for selecting a house in a housing estate. It combines dwelling unit with all other infrastructure, recreational and other facilities. With the busy current lifestyle, people would like to have all of their requirements at their fingertips. Most of the developers offer a strategic solution to these requirements by introducing housing estates with many other facilities.

Third, people would like to have a pleasant neighbourhood. Housing estates provide a better neighbourhood compared to other modes. Residents of a housing estate belong to the same social group and strata.

Fourth, location of the housing estate and accessibility are other factors a customer look for when buying a house from a housing estate. If the estate is remote from other facilities such as hospitals, bus stands, railway stations, shopping malls and banks; the level of customer attraction is low.

Finally, security is found to be an important factor in buying a house in an estate. Customers such as businessmen; foreigners who regularly come for their vacations; and, Sri Lankans expatriates mostly consider this security factor.

\section{Measuring customer satisfaction}

The biggest shift in the housing estate industry in the last two decades is that builders are strongly oriented towards increasing their customer base. Satisfied customers are said to be the backbone of the housing estate industry. Builders have realized that the ability to correctly assess the desirability of their housing units and the quality of services are crucial to their financial viability. Customers are more informed, more aware, and more knowledgeable, about the factors that are related to their satisfaction or dissatisfaction. As far as qualitative aspects of housing are concerned, a satisfactory residential environment is expressed in terms of both physiological needs such as comfort, protection from external elements and psychological needs such as community and family life. This is a universal phenomenon and Sri Lanka is no exception.

Kotler et al (2000) define customer satisfaction as "the extent to which a product perceived performance matches a buyers expectations." If the product performance falls short of expectations the buyer is dissatisfied. If the performance matches or exceeds expectations the buyers is satisfied or delighted. There are, however, no commonly accepted methods of measuring customer satisfaction in the property industry. 
Customer satisfaction in the property industry offers several benefits. For example, it will lead to lower marketing cost as satisfied customers are an effective source of advertisement to contractors and developers. On the contrary, dissatisfied customers can cause severe damage to a builder's reputation. Lower selling cost is another benefit derived through such satisfied customers. Further, warranty costs will be less as satisfied customers make fewer complaints than those who are less satisfied. Among other benefits, satisfied clients always cause to develop the goodwill of the contractor and hence contractor may get more and more construction works.

Previous studies have suggested that the customer satisfaction depend not only upon the product itself, but also upon experience surrounding the acquisition of the product (Hempel, 1977). Consequently every product and service must be designed, produced and delivered in the context of a total package of products and services. It is a total offering that generates the total degree of customer satisfaction. Taking this total quality concept into consideration, a customer satisfaction model is developed in this study to measure the satisfaction level of users of the housing estates as given in Figure 01.

In the model the term product refers to the house/ physical dwelling unit. The term services, as used in the model, represent the customer services provided by the developer. The proposed model assumed that the user satisfaction extend beyond the dwelling unit itself.

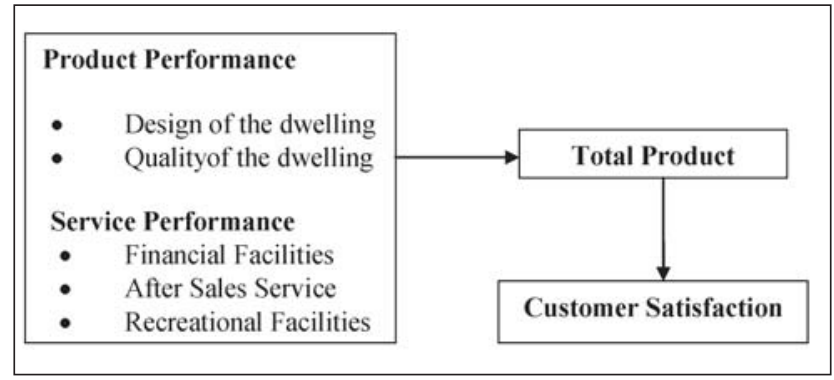

Figure 01: Customer Satisfaction Model

Based on the proposed model and further literature review, parameters for measuring customer satisfaction were developed. It consists of 26 parameters; 13 representing product performance and 13 service performance. Product performances further divided into dwelling design and quality. Service performance parameters are further divided into financial services, after sales services and the environment quality of the housing estate.

\section{Results of the customer satisfaction survey}

The survey results showed that, in most of the cases number of members in a house is 3 . There were few houses with number of members more than 5 as given in Figure 02. These housing estates are more suited for small families.

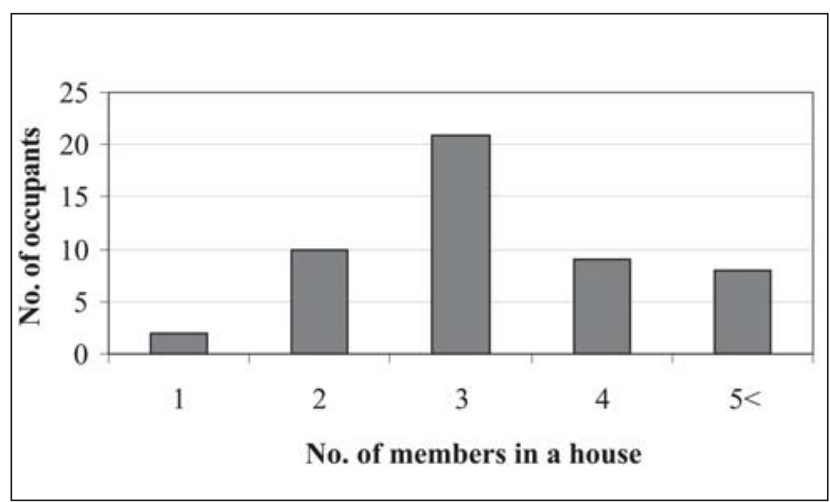

Figure 02: No of members in a house

When asked about the prior residence of the occupants, survey revealed that most of the occupants had lived with parents or in rented houses. People who had their own houses had rarely moved to the housing estate as shown in Figure 03.

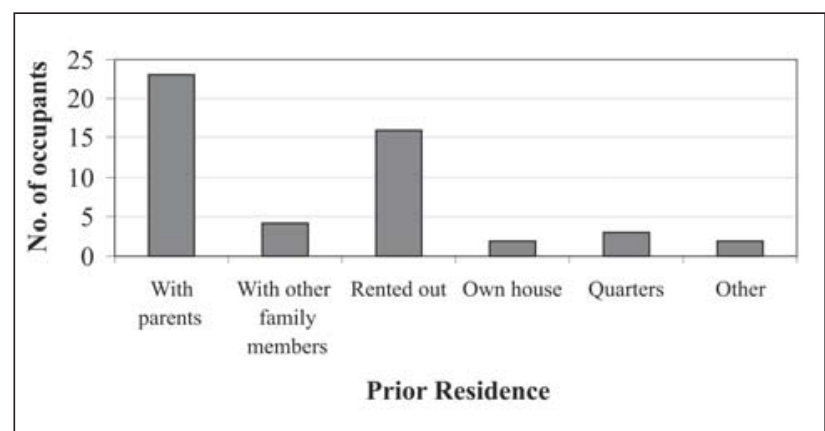

Figure 03: Prior residence

The survey revealed a varied tenure pattern in those housing estates with a very high representation of owner in possession of property (refer Figure 04). The percentage of owner in possession of properties is about $70 \%$ in those housing estates.

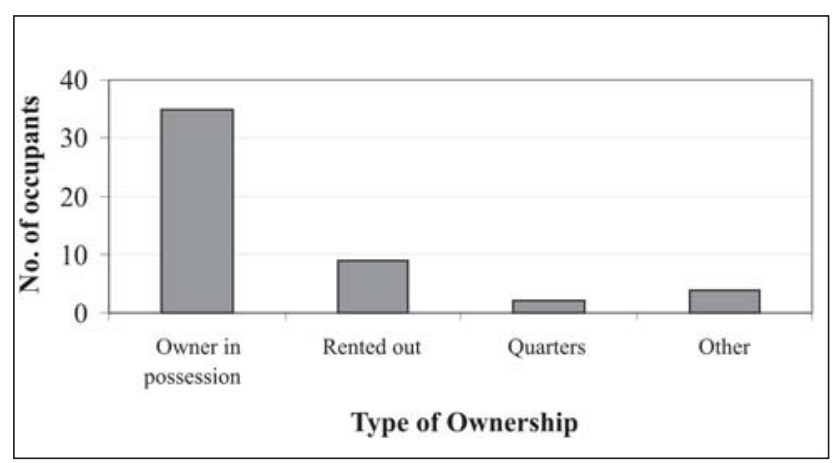

Figure 04: Type of ownership

Personal savings was the main mode of finance for purchasing a house from a housing estate as given in Figure 05. This is because most of the home buyers are businessmen or Sri Lankan expatriates. They can afford to buy a house with the savings. However, house buyers who work for salary were found to be dependant on loan facilities. 


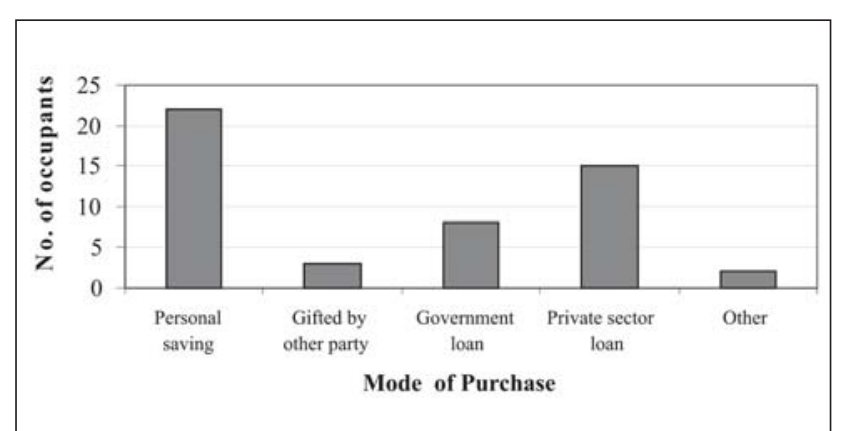

Figure 05: Mode of finance

Majority of the buyers in these schemes were businessmen followed by private sector employees as given in Figure 06.

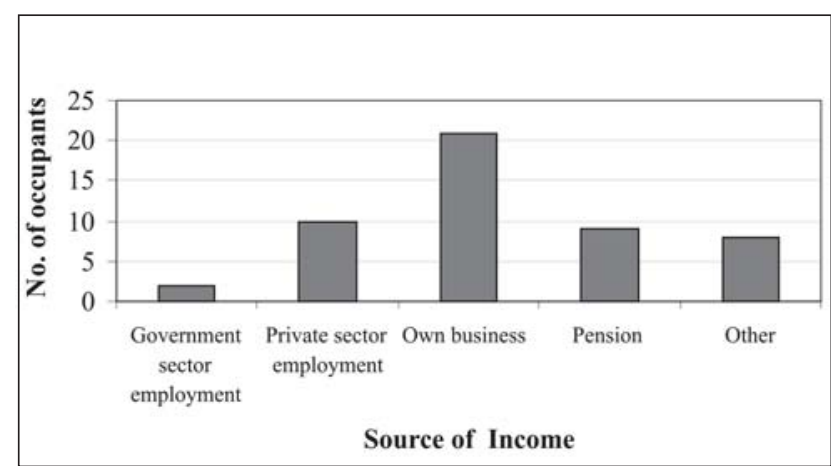

Figure 06: Source of income

The more expensive the product the greater the customer expectations. The purchase of a house is one of the most expensive purchases a person will ever make and is often judged more harshly. On that ground it is necessary to identify the key criterion that is used by the customers to evaluate the different alternatives available in the housing market. Figure 07 illustrates the attributes a customer considered, when purchasing a house from a housing estate.

Customers have given the highest priority to design and quality of the house, followed by after sales services and then the environment quality.

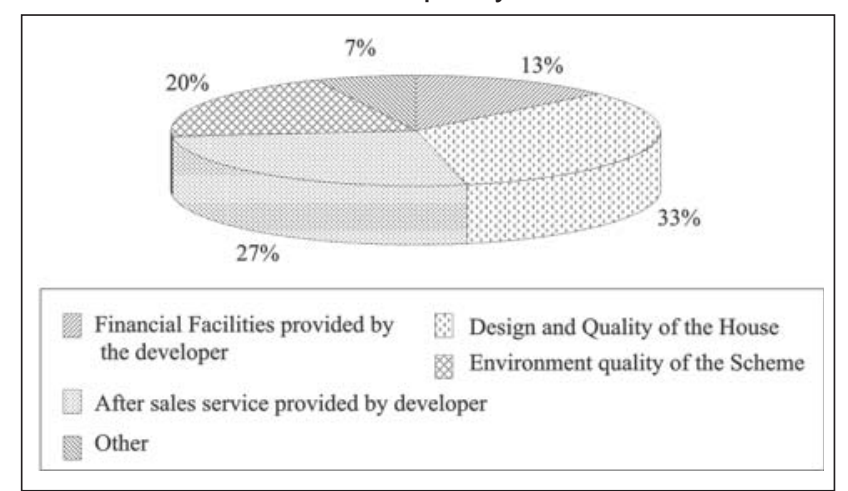

Figure 07: Key selection criteria used for purchasing a house

The study went into detail on the three attributes which got highlighted above as most important in terms of customer satisfaction.

\section{Design and quality of the house}

Customer Satisfaction in terms of design was measured using 7 parameters as given in Figure 08. The mean satisfaction level of the each parameter was measured using a Likert scale ranging from 1 to 5.

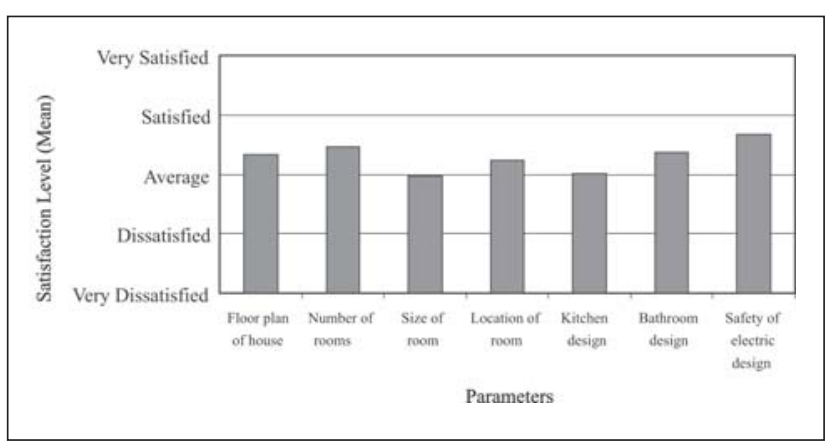

Figure 08: Customer satisfaction in terms of design

Figure 08 reveals that customers' satisfaction on design of the house is average. Another six parameters were used to measure the satisfaction in terms of quality (refer Figure 09).

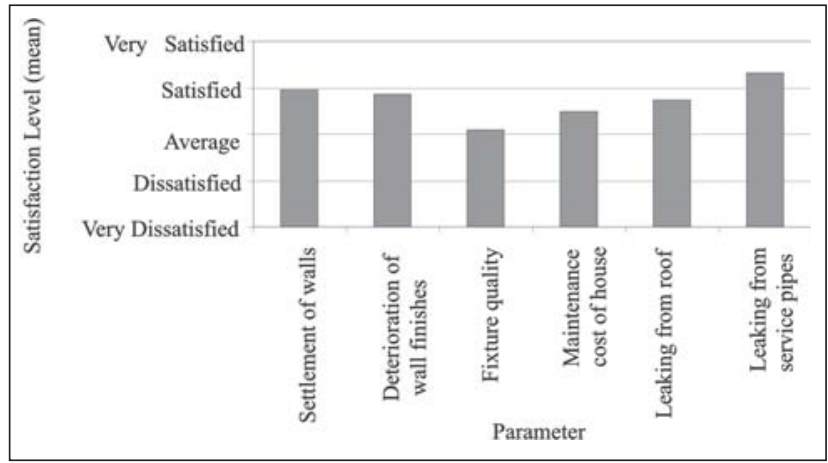

Figure 09: Customer satisfaction in terms of quality

Figure 09 illustrates that house owners show an above average satisfaction level in terms of quality.

\section{After sales services provided by the developer}

Satisfaction on after sales services provided by developer was measured using 5 parameters. Figure 10 illustrates the satisfaction level of after sales services.

\section{Environmental quality of scheme}

Three parameters were used to measure the environment quality satisfaction level as given in Figure 11. 


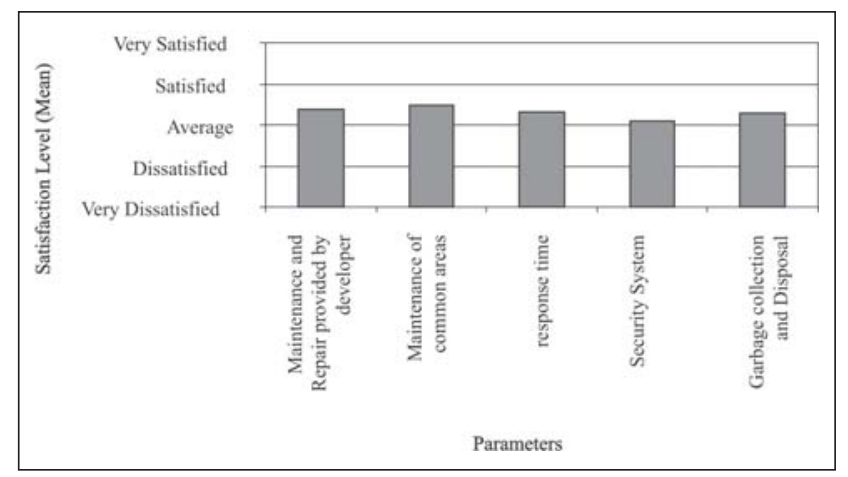

Figure 10: satisfaction level on after sale services

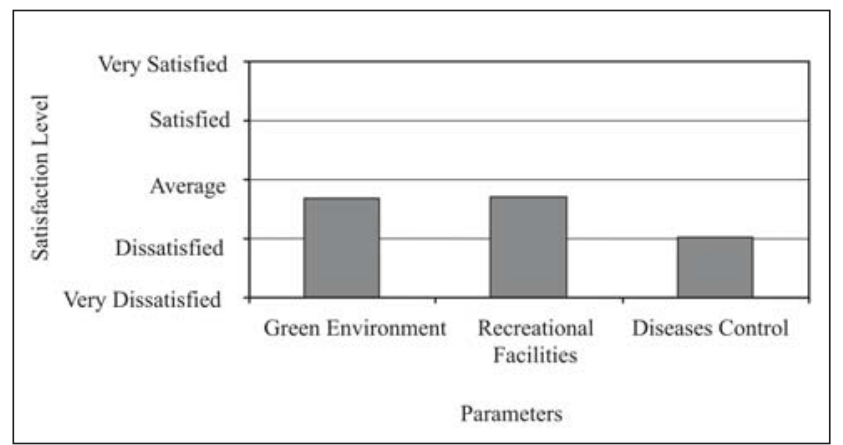

Figure 11: satisfaction levels on the environmental quality of the schemes

\section{User recommendation for house buyers}

The study also explored the recommendations of the current users (residents) for new house buyers. Table 01 tabulates their recommendation to purchase a house from any housing estate, against the recommendation to purchase a house from the housing estate they currently reside. It reveals that $70 \%$ (i.e. $4+66$ ) users recommend purchasing from a housing estate. But only $48 \%$ (i.e. $8+40$ ) recommend purchasing from the estates they currently reside. This indicates that current customers agree that a housing estate would provide the best solution for their housing needs, but are slightly dissatisfied with the solution offered to them by the current scheme.

Table 01: Recommendation of customers on purchasing a house from any housing estate verses purchasing from the estate that customer currently resides

\begin{tabular}{|c|c|c|c|c|c|c|c|}
\hline & \multicolumn{6}{|c|}{ Purchase from current housing estate $(\%)$} & \multirow{2}{*}{$\begin{array}{l}\text { Total } \\
(\%)\end{array}$} \\
\hline \multirow{6}{*}{ 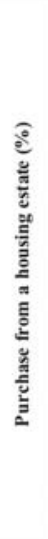 } & & 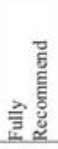 & 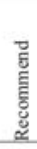 & $\frac{3}{2}$ & 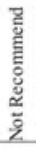 & 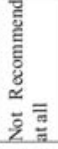 & \\
\hline & Fully Recommended & 4 & & & & & 4 \\
\hline & Recommended & 4 & 38 & 14 & 4 & 6 & 66 \\
\hline & No View & & 2 & 10 & 4 & 2 & 18 \\
\hline & Not Recommended & & & & 6 & 2 & 8 \\
\hline & Not Recommended at all & & & & 2 & 2 & 4 \\
\hline $\begin{array}{c}\text { Total } \\
(\%)\end{array}$ & & 8 & 40 & 24 & 16 & 12 & 100 \\
\hline
\end{tabular}

\section{Conclusion}

With the scarcity of land in the urban areas coupled with population growth and sophistication in lifestyles of the people, the demand for "Ready Made Houses" has increased. Due to this rapid rise of demand the developers keep on constructing housing estates regularly. According to them, the demand for these houses are guaranteed and made in advance, thus no worry over selling the houses. As a result, new firms are emerging day by day. "Rapid roll out" projects are witnessed in highly urbanized residential areas. This high demand could result in positive attributes such as economies of scale and advantage of specialization that enhance the resource efficiency and industry performance. On the other hand this opportunity may lead to some developers taking advantage by delivering a poor quality product. In this context, this study was focused on ascertaining the characteristics of a housing development that affect its attractiveness and saleability, and to investigate the current status of customer satisfaction levels in housing estates in Sri Lanka.

From the point of view of property developers; location, design, prices and flexible payment schemes; reputation and experience of the developer; quality of the dwelling unit; and services offered, were key factors affecting the saleability of a housing estate.

Using a model, the study identified that the customers have a slightly above average satisfaction level in the overall context. Design and quality, and after sales services, show a significant priority over other factors in the selection criteria of purchasers. Availability of land to provide all necessary infrastructure and green open areas are vital in housing estate development as the target group for this market particularly look for such features in addition to the houses.

\section{References}

Barsky, J. and Labagh, R., (1990), A strategy for customer satisfaction, The Cornel H.R.A Quarterly, Oct 32-40

Brown, J.R. and Lern, E.F., (1981), Goods Vs Service Marketing, A Divergent Perspective: Marketing of services, Construction engineering, ACSC, 117(2) 341-359

Dissanayake, D.R.S., (2004), Study of housing supply and changing user requirements in Sri Lanka, unpublished undergraduate dissertation, Department of Building Economics, University of Moratuwa, Sri Lanka.

Eccles, R.G., (1991), The Performance Measurement Manifesto, Harvard Business Review. Jan-Feb 31137. 
Eccles, R.G., and Pybum, P.J., (1992), Creating comprehensive system for measure performance, Management Accounting Oct 41-44

Hempel, G.E., (1977), Marketing Strategies for Beginners, Belvor \& Chatter; N.J.

Johnson, M.D. and Fornell, C., (1991), A frame for comparing the customer satisfaction across individual product categories, J. Economic Phylosopy 12, 267-286

Kotler, K.D., (1995), Customer Satisfaction in Property Market, 2nd ed, Fredman Publishers; London.

Kowshala, N., (2002), Proliferation of condominium development in Sri Lanka, unpublished undergraduate dissertation, Department of Building Economics, University of Moratuwa, Sri Lanka.

Maloney, W.F., (1990), Framework for analysis performances, J. Construction engineering, ACSC, 116(3) 399-415

Marga Institute, (1986), Housing Development in Sri Lanka 1971-1981, Sri Lanka Centre for Development Studies, Colombo.

Nandagopan, V., (2005), An analysis of selling pattern of the semi-luxury houses in Western province of Sri Lanka, unpublished undergraduate dissertation, Department of Building Economics, University of Moratuwa, Sri Lanka.
Peters, T.J and Waterman, R.W., (1987), In search of excellence lesson from America's best run companies, Harper and Row, New York

Sanvido, V.E., (1988), Conceptual construction process model, Construction engineering, ACSC, 116(3) 294312

Sawn, J.E. and Combs, L.J., (1990), Product Performance Consumer Satisfaction, A new concept, Journal of Marketing 40(April) 25-33

Zairi, M., (1989), Managing customer satisfaction: A best perspective, The TQM magazine. МСB University press, 2(11) 389-394

Web Sites

1. http://www.ceylimncohousing.lk, (Accessed on $8^{\text {th }}$ May 2006)

2. http://www.epa.gov/fedrgstr/EPA-AIR/2000/Auqust/ Day-04/a19785.htm, Environmental Protection Agency, (Accessed on 10 $10^{\text {th }}$ May 2006)

3. http://www.ibm.org.com, (Accessed on $10^{\text {th }}$ May 2006)

4. http://www.icc-construct.com, (Accessed on $8^{\text {th }}$ May 2006)

5. http://www.icelandresidencies.com, (Accessed on $9^{\text {th }}$ May 2006)

6. http://www.kelseyhomeslanka.com, (Accessed on $8^{\text {th }}$ May 2006)

7. http://www.nivasie.com, (Accessed on $9^{\text {th }}$ May 2006) 